\title{
The Chemistry of Gold
}

\section{RECENT ADVANCES IN THE COORDINATION AND ORGANOMETALLIC FIELD}

\author{
Brian F. G. Johnson \\ University Chemical Laboratory, Cambridge
}

\section{This review describes first the basic chemistry of gold and then goes on to deal with both organo-gold compounds and compounds containing gold-metal bonds. These are of immediate interest because of their potential uses both as catalysts and as reagents in the prepara- tion of organic derivatives.}

It is remarkable that, although gold has occupied the minds of alchemists or chemists for centuries, until recently its chemistry was virtually unexplored. To the ancients it had seemed plausible to believe that gold was the "ultimate" metal and that all other base metals could be converted to it by some simple "magical" process. This idea did not, of course, end with the ancients; it remained a long-held philosophic idea and even today has a certain attraction.

The special interest of gold is connected with its value as a metal. Consequently the development of its chemistry has been mainly concerned with metallurgical processes. Chemical compounds employed for the production of gold film as decoration have been developed, but the chemistry of these materials remains, in many instances, little understood although they are among the most important gold compounds if the criterion of importance is widespread industrial use.

The object of this review is to give a concise, although not exhaustive, description of the chemistry of gold and to consider three main aspects:

(i) fundamental aspects-occurrence in the periodic table, oxidation states, and stereo-chemistries;

(ii) organo-gold compounds;

(iii) compounds containing gold-metal bonds.

\section{General Chemistry}

Gold has the valence electronic configuration $6 s^{2} 5 d^{9}$. It may, therefore, be regarded as a transition metal and it is a member of the copper triad, copper, silver, and gold. Unlike most other transition metal triads there is little resemblance, bar certain physical properties, between the third and second members of this group.

Gold is found in two main oxidation states. The aurous ion $\left(\mathrm{Au}^{+}\right)$has a transitory existence and readily converts into the auric ion $\left(\mathrm{Au}^{\mathrm{g}+}\right)$, and it is noteworthy that $\mathrm{AuCl}$ is decomposed by water to gold metal and a hydrolysed auric species ( $c f \mathrm{AgCl}$ ). However, several complex anions containing $\mathrm{Au}^{+}$ stable in water are known, e.g. $\left[\mathrm{Au}(\mathrm{CN})_{2}\right]^{2--}$. Compounds and complexes containing $\mathrm{Au}^{3+}$ are more common. No authentic examples of bivalent gold are known.

The most important coordination number for the aurous ion is two and complexes of this ion have a linear geometry. For gold(III) the common coordination number is four and a square planar geometry is favoured although there is evidence of compounds containing this ion in five or six coordinate environments (with trigonal pyramidal and octahedral structures respectively) e.g. $\left[\mathrm{Au}(\text { diars })_{2} \mathrm{I}\right]^{2+}$ and $\left[\mathrm{Au}(\text { diars })_{2} \mathrm{I}_{2}\right]^{3 \cdot}$.

The best characterised simple compounds of gold are possibly the trihalides, $\mathrm{AuX}_{3}(\mathrm{X}=\mathrm{F}, \mathrm{Br}$ or $\mathrm{Cl})$. Gold trifluoride has a unique structure with no analogue in the transition series. The structure consists essentially of a square planar arrangement of $F$ about each gold atom with planar units building up into a spiral. Gold trichloride; a red crystalline solid, is dimeric and consists of two planar $\mathrm{AuCl}_{4}$ units sharing an edge. The structure of $\mathrm{AuBr}_{3}$ has not been reported. Complex halo-ions of the type $\mathrm{AuX}_{4}-(\mathrm{X}=\mathrm{F}, \mathrm{Cl}$ or $\mathrm{Br})$ are also known. The salt $\mathrm{Cs}_{2} \mathrm{Au}_{2} \mathrm{Cl}_{6}$ consists essentially of equal amounts of $\mathrm{AuCl}_{4}-$ and $\mathrm{AuCl}_{2}-$ ions.

\section{Organo-gold Compounds}

Organometallic compounds have intrigued both the experimental and theoretical chemist since their discovery. Their use as catalytic or synthetic reagents has been realised and well exploited. Even so, interest in such compounds continues to increase and no doubt other important uses will be found. At 
present no important application of organo-gold compounds has been reported. This is an area ripe for investigation since some of the best catalytic reagents are similar compounds of the platinum metals. Here a summary of organo-gold compounds will be given.

\section{Gold Alkyls and Aryls}

These were among the first transition-metal alkyl derivatives to be obtained. It is surprising, therefore, that so little of their chemistry has been examined. Alkyl and aryl complexes of both gold(I) and gold(III) are known. This is in contrast to both copper and silver which form derivatives only for the $+I$ oxidation state. Gold(I) $\sigma$-bonded organo-complexes are prepared by the general method:

\section{$\mathrm{R}_{3} \mathrm{PAuX}+\mathrm{R}^{\prime} \mathrm{MgX} \longrightarrow \mathrm{R}_{\mathrm{s}} \mathrm{PAuR}^{\prime}$ (or $\mathrm{LiR}^{\prime}$ )}

Linear compounds are produced. Auric complexes are prepared in a related fashion. Thus auric bromide reacts with $\mathrm{LiMe}$ at $-65^{\circ} \mathrm{C}$ in ether to produce $\mathrm{AuMe}_{3} \cdot \mathrm{Et}_{2} \mathrm{O}$ as a highly unstable species. At $-40^{\circ} \mathrm{C}$ this complex decomposes to produce a gold mirror. More stable derivatives, e.g., $\mathrm{AuMe}_{3} \mathrm{PR}_{3}$ may be obtained from the reaction of the etherate with tertiary phosphines at $-80^{\circ} \mathrm{C}$.

$\mathrm{AuBr}{ }_{3}+\left.\mathrm{Li} \mathrm{Me} \underset{-65^{\circ} \mathrm{C}}{\longrightarrow} \mathrm{Me}_{3} \mathrm{Au}_{\text {Aut }}\right|_{4}{ }_{2} \mathrm{O} \frac{\mathrm{R}_{3} \mathrm{P}}{-80^{\circ} \mathrm{C}} \mathrm{R}_{3} \mathrm{P} . \mathrm{AuMe}_{3}$

The thermal decomposition of $\mathrm{Ph}_{3} \mathrm{PAuMe}_{3}$ gives ethane, $\mathrm{Ph}_{3} \mathrm{PAuMe}$ and finally $\mathrm{PPh}_{3}$ and gold. An outline of the general reactions of alkyl-gold(III) compounds is given in the scheme.
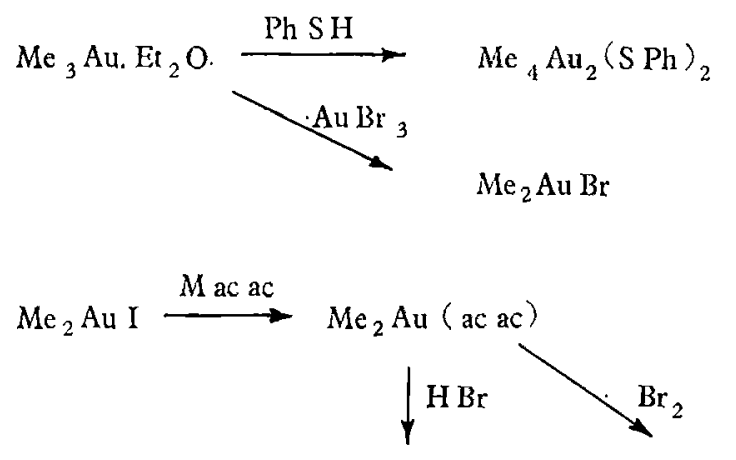

$\mathrm{Br} \mathrm{Au} \mathrm{Me}{ }_{2}$

$\mathrm{Br}_{2} \mathrm{Au} \mathrm{Me}$

Gold Acetylides and Related Compounds

Gold acetylide, $\mathrm{Au}_{2} \mathrm{C}_{2}$, has been known for some considerable time. Like the analogous compounds of copper and silver, it is explosive. Related alkynyl complexes $[\mathrm{Au}(\mathrm{C} \equiv \mathrm{CR})]_{\mathrm{n}}$ have also been reported.
These may be prepared by the direct reaction of the appropriate alkyne with gold(III) chloride :

$$
\begin{gathered}
\mathrm{AuCl} \cdot \mathrm{aq}+\mathrm{KBr} \underset{\mathrm{I} \text { reduction with }}{\stackrel{\mathrm{aq} / \text { acetone } 20^{\circ} \mathrm{C}}{\mathrm{S} \mathrm{O}_{2}}}[\mathrm{PhC} \equiv \mathrm{CAu}] \mathrm{n} \\
2 \quad \text { addition of } \\
\mathrm{PhC} \equiv \mathrm{CPl}
\end{gathered}
$$

For the $t$-butyl alkyne complex $\left[\mathrm{AuC}=\mathrm{CBu}^{\mathrm{t}}\right]_{\mathrm{n}}$, values of 4 and 8 have been established for $n$. Treatment of these polymeric compounds with ligands (L) such as tertiary phosphines or amines gives simple products of the type $(\mathrm{LAuC}=\mathrm{CR})_{\mathrm{m}}$. The amine complexes are associated with values of $\mathrm{m}$ in the range 2.6 to 4.1 .

\section{Olefin Complexes}

Gold(I) and gold(III) form complexes with cycloocta-1,5-diene

$$
\mathrm{HAuCl}_{4}+\mathrm{C}_{8} \mathrm{H}_{12} \stackrel{\mathrm{Et}_{2} \mathrm{O}}{\longrightarrow} \mathrm{Cl}-\mathrm{Au}-\mathrm{C}_{8} \mathrm{H}_{12}-\mathrm{Au}-\mathrm{Cl}
$$

Some related complexes with norbornadiene are also known. In general few studies have been carried out in this area.

\section{Compounds Containing Gold-Metal Bonds}

One of the more interesting and recent developments in the field of inorganic chemistry has been the study of compounds containing metal-metal bonds. At one time with few exceptions these compounds were unknown; now they are legion. For convenience they may be classified into two types:

(a) Simple compounds containing direct metalmetal bonds, examples of this class are $\mathrm{Hg}_{2} \mathrm{Cl}_{2}$ and $\mathrm{Mn}_{2}(\mathrm{CO})_{10}$.

(b) Cluster compounds containing metal atoms in discrete polyhedral arrangements, e.g., a tetrahedron in $\operatorname{Ir}_{4}(\mathrm{CO})_{12}$ and an octahedron in $\mathrm{Rh}_{6}(\mathrm{CO})_{1 \mathrm{~g}}$. $\therefore \rightarrow$.

Such compounds are of interest for many reasons, one of the most important being the wide range of structural types which they exhibit. In both classes not only are homo-nuclear systems known (i.e., all metal atoms the same) but also heteronuclear systems containing two or more different metals.

Numerous compounds containing gold-metal bonds have been characterised. In general they are prepared by a pseudo-Wurtz reaction, e.g. :

$\mathrm{Ph}_{3} \mathrm{PAuCl}+\mathrm{NaMn}(\mathrm{CO})_{6} \longrightarrow \mathrm{Ph}_{3} \mathrm{PAuMn}(\mathrm{CO})_{5}+\mathrm{NaCl}$

Among the most common gold-metal compounds known are those containing gold-manganese bonds, $\mathrm{LAuMn}(\mathrm{CO})_{6}, \quad\left[\mathrm{~L}=(\mathrm{PhO})_{3} \mathrm{P}, \quad\left(p-\mathrm{MeO}-\mathrm{C}_{6} \mathrm{H}_{4}\right)_{3} \mathrm{P}\right.$, $\mathrm{Ph}_{3} \mathrm{As}$, and $\mathrm{Ph}_{3} \mathrm{Sb}$ and $\mathrm{Ph}_{3} \mathrm{PAuMn}(\mathrm{CO})_{4} \mathrm{~L}^{\prime}\left[\mathrm{L}^{\prime}=\right.$ $\mathrm{Ph}_{3} \mathrm{P},(\mathrm{PhO})_{3} \mathrm{P}, \mathrm{Ph}_{3} \mathrm{As}$ and pyridine]. The reactions of 
these compounds have been carefully studied and their reactivity is similar to that shown by the carbonyl halides, $\mathrm{Mn}(\mathrm{CO})_{5} \mathrm{X}(\mathrm{X}=\mathrm{Cl}, \mathrm{Br}$ or $\mathrm{I})$, suggesting that the $\mathrm{Ph}_{3} \mathrm{PAu}$ group is behaving to some degree like a pseudo-halogen. Other compounds containing $\mathrm{Au}-\mathrm{Co}$ and $\mathrm{Au}$. Fe are also known, e.g., $\mathrm{Ph}_{3} \mathrm{PAuCo}(\mathrm{CO})_{4}$, and $\left(\mathrm{Ph}_{3} \mathrm{PAu}\right)_{2}-\mathrm{Fe}(\mathrm{CO})_{4}$.

An interesting bidentate gold "ligand" has been prepared:

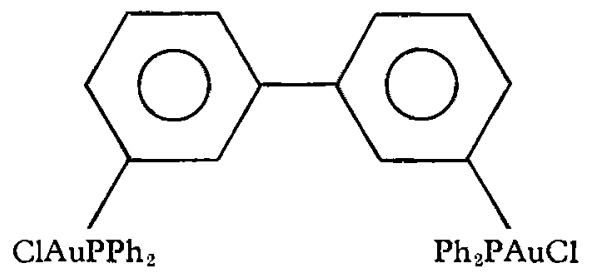

This readily forms complexes with, for example, $\mathrm{H}_{2} \mathrm{Fe}(\mathrm{CO})_{4}$ :<smiles></smiles>

(Organic section omitted for clarity)

Gold also forms stable bonds with main group metals. Triphenylgermyllithium, $\mathrm{Ph}_{3} \mathrm{GeLi}$, reacts with $\mathrm{P}_{3} \mathrm{PAuX}$ compounds to form complexes with
Au-Ge bonds. Corresponding compounds containing $\mathrm{Cu}-\mathrm{Ge}$ and $\mathrm{Ag}-\mathrm{Ge}$ bonds are also known. The stability of the metal-metal bond decreases in the order $\mathrm{Au}-\mathrm{Ge}>\mathrm{Ag}-\mathrm{Ge}>\mathrm{Cu}-\mathrm{Ge}$.

Several polynuclear compounds containing gold aggregates have been reported. In general they are prepared by the reduction of suitable phosphine-gold halide complexes with sodium borohydride, e.g.,

$$
\mathrm{Ph}_{3} \mathrm{PAuCl} \frac{\mathrm{NaBH}_{4}}{\mathrm{H}_{2} \mathrm{O}} \rightarrow \text { " } \mathrm{Au}_{5}\left(\mathrm{Ph}_{3} \mathrm{P}\right)_{4} \mathrm{Cl} "
$$

Initial work suggested structures based on three, five, and six gold atoms but later X-ray studies indicated that a number of these complexes may be much more complex. A triphenylphosphine complex which, on the basis of analytical data, was believed to be $\mathrm{Au}_{6} \mathrm{~L}_{6}(\mathrm{CNS})_{2}$ has now been recognised as $\mathrm{Au}_{11} \mathrm{~L}_{7}(\mathrm{SCN})_{3}$. A central gold atom is surrounded by ten remaining gold atoms each of which has one ligand attached to it. The structure is best described approximately as a combination, by apex sharing, of a pentagonal bipyramid and square pyramid with gold atoms at all vertices. Clusters containing ten, twelve, and thirteen gold atoms have been predicted.

\section{Conclusion}

The chemistry of gold is virtually unexplored. Two main areas worthy of current interest are the preparation of organo-gold compounds and of compounds containing gold-metal or gold-gold bonds. Indeed, preliminary data at present available on other related systems have shown that such compounds have pronounced catalytic activity.

\section{Gold Alloys for Cardiac Pacemakers}

\section{ELECTROCATALYSTS IN BODY IMPLANTABLE FUEL CELLS}

The technique of cardiac pacemaking is now firmly established, and it is estimated that in the United States alone there are 50,000 patients carrying permanently implanted pacemakers. Problems of longevity of the mercury-zinc cell normally used as a source of power are, however, giving concern and efforts are being directed towards the use of either nuclear power or of a fuel cell to promote longer life.

At the Fall Meeting of the Electrochemical Society in Atlantic City a number of papers dealt with this subject, particularly with the idea of utilising the oxidising and reducing substances normally found in the blood stream both as reactants and as electrolyte in an implantable fuel cell. This concept requires selective electrocatalysts for hydrocarbon oxidation at the anode and for oxygen reduction at the cathode, and several groups of workers are at present exploring this field.
One paper, by J. H. Fishman and J. F. Henry of Leesona Moos Laboratories, reported a study of alloys in the gold-palladium system which they had found to satisfy the selectivity requirement in tests with simulated and natural blood. Significant transitions in the bulk properties of these alloys occur in the 35 and the 60 atomic per cent gold regions, and it was found that their catalytic properties similarly undergo transitions in the same composition regions. The gold-palladium system thus gives a remarkable spectrum of electrocatalytic properties, some alloys being substantially selective for the anodic process while others are selective for the cathodic process in a dissolved mixture of oxygen and oxidisable hydrocarbons.

The authors were successful in deriving electric power with such oppositely selective electrodes from flowing oxygenated human blood. 